\begin{tabular}{|c|l|}
\hline Title & Origins of hydrocarbons in the Sagara oil field, central Japan \\
\hline Author(s) & Toki, Tomohiro; Gamo, Toshitaka; Tsunogai, Urumu \\
\hline Citation & $\begin{array}{l}\text { Island Arc, 15(3), 285-291 } \\
\text { https://doi.org/10.1111’.1440-1738.2006.00528.x }\end{array}$ \\
\hline Issue Date & 2006-09 \\
\hline Doc URL & http://hdl.handle.net/2115/29654 \\
\hline Rights & The definitive version is available at www.blackwell-synergy.com \\
\hline Type & article (author version) \\
\hline File Information & IA 15-3-285.pdf \\
\hline
\end{tabular}

Instructions for use 


\title{
Origins of hydrocarbons in the Sagara oil field, Central
}

\section{Japan}

\author{
Tomohiro Toki ${ }^{\text {a, } 1, *}$, Toshitaka Gamo ${ }^{\text {a, } 1}$, Urumu Tsunogai ${ }^{\text {a }}$ \\ ${ }^{a}$ Division of Earth and Planetary Sciences, Graduate School of Science, Hokkaido University, N10 W8,
}

Kita-ku, Sapporo 060-0810, Japan.

${ }^{1}$ Present address: Marine Inorganic Chemistry Group, Department of Chemical Oceanography, Ocean

Research Institute, The University of Tokyo, 1-15-1, Minamidai, Nakano-ku, Tokyo 164-8639, Japan.

* Corresponding author. Tel.: +81 (3) 5351-6453; Fax: +81 (3) 5351-6452.

E-mail address: toki@ori.u-tokyo.ac.jp (Tomohiro Toki).

\section{ABSTRACT}

We collected free gas and in situ fluid samples up to a depth of $200.6 \mathrm{~m}$ from the Sagara oil field, Central Japan $\left(34^{\circ} 44^{\prime} \mathrm{N}, 138^{\circ} 15^{\prime} \mathrm{E}\right)$, during the Sagara Drilling Program (SDP) and measured the concentrations and stable carbon isotopic compositions of $\mathrm{CH}_{4}$ and $\mathrm{C}_{2} \mathrm{H}_{6}$ in the samples. A combination of the $\mathrm{CH}_{4} / \mathrm{C}_{2} \mathrm{H}_{6}$ ratios 
with the carbon isotope ratios of methane indicates that the hydrocarbon gases are predominantly of thermogenic origin at all depths. The isotope signature of hydrocarbon gases of $\delta^{13} \mathrm{C}_{\mathrm{CH} 4}<\delta^{13} \mathrm{C}_{\mathrm{C} 2 \mathrm{H} 6}$ suggests that these gases in the Sagara oil field are not generated by polymerization, but by the decomposition of organic materials.

Keywords: Sagara oil field, SDP, hydrocarbons, free gas, in situ fluid, carbon isotope, thermogenic origin, microbial origin

\section{INTRODUCTION}

The Sagara oil field, in the southern part of Shizuoka prefecture, is the only oil field on the Pacific Ocean side of the Japan Islands (Fig. 1). The region is composed of conglomerate, sandstone, mudstone, and limestone, which are considered to be forearc basin sediments on the Nankai accretionary prism, presently developing in the southward of the Sagara field (e.g. Tsuchi 1961; Ujiie 1962; Ibaraki 1986; Shiba et al. 1996; Shiba et al. 1997). This oil field is unique from many geological, geophysical, 
and geochemical perspectives (e.g. Uemura \& Yamada 1988; Kato 1992; Morikawa \& Imanaka 1993; Morikawa et al. 1998; Tanaka et al. 1999). First, Sagara oil is light rather than ordinary oil (Kato 1992). Second, the oil reservoir is found in a shallow layer; and third, heat flow data sets suggest there is no local heat source in the adjacent area (Tanaka et al. 1999). The production of Sagara oil has been explained by two different processes: (1) the formation at a greater depth (Uemura \& Yamada 1988) and subsequent upward migration on the basis of the carbon isotope ratio of the Sagara oil (Kato 1992); (2) formation by the action of a petroleum-degrading bacterium grown anaerobically with $\mathrm{CO}_{2}$ and $\mathrm{H}_{2}$ (Morikawa \& Imanaka 1993), which forms alkane/alkene with carbon numbers from 14 to 30 in addition to fatty acids inside the cell (Morikawa et al. 1998). If the latter process does occur, the chemical and stable carbon isotopic compositions of hydrocarbon gases from the oil field should provide evidence of microbial activity (e.g. Rice \& Claypool 1981; Schoell 1983; Berner \& Faber 1993; Sackett et al. 1968). To test these hypotheses, the Sagara Drilling Program (SDP) was conducted by Hirano et al. (this volume) at the Sagara oil field from January 31 to March 17, 2002 to obtain drilling cores, in situ fluids, and logging data. 
Gaseous hydrocarbons and their carbon isotope composition $\left(\delta^{13} \mathrm{C}\right)$ have been used by many researchers to determine the origin of hydrocarbons and the hydrocarbons-forming processes in natural environments. The origin of hydrocarbons can be broadly divided into microbial and thermogenic. The microbial gas is formed by methane production from $\mathrm{CO}_{2}$ and $\mathrm{H}_{2}$ through $\mathrm{CO}_{2}$ reduction by microbes and the thermogenic gas is due to the thermal degradation of organic matter. The hydrocarbons of microbial origin consist predominantly of methane. As much as $2 \%$ of the heavier hydrocarbons produced in this way, and the associated methane is depleted in the heavy isotope ${ }^{13} \mathrm{C}$ (with a $\delta^{13} \mathrm{C}$ value less than $-55 \%$ ) due to kinetic isotope fractionation by methanogens (Rice \& Claypool 1981). In contrast, the hydrocarbon fraction of thermogenic gas consists of relatively heavier hydrocarbons, and thermogenic methane is enriched in ${ }^{13} \mathrm{C}$ (Schoell 1983). $\mathrm{A} \delta^{13} \mathrm{C}_{\mathrm{CH} 4}$ value of less than $-55 \%$ and a $\mathrm{CH}_{4} / \mathrm{C}_{2} \mathrm{H}_{6}$ ratio of greater than $10^{2}$ are diagnostic of gas of microbial origin, while a $\delta^{13} \mathrm{C}_{\mathrm{CH} 4}$ value of greater than $-50 \%$ and a $\mathrm{CH}_{4} / \mathrm{C}_{2} \mathrm{H}_{6}$ ratio of less than 10 indicate gas of thermogenic origin (Berner \& Faber 1993).

The hydrocarbons-forming processes consist of (1) carbon-carbon bond 
breakages of heavier hydrocarbons, or (2) the bond syntheses of lighter hydrocarbons.

The relative distribution of carbon isotope ratios of gaseous hydrocarbons has been used to classify these processes. During carbon-carbon bond breakages of heavier hydrocarbon molecules, a ${ }^{12} \mathrm{C}-{ }^{12} \mathrm{C}$ bond is easier to break than a ${ }^{13} \mathrm{C}-{ }^{13} \mathrm{C}$ bond, resulting in the orderly distribution of hydrocarbons in which methane is isotopically lightest among gaseous molecules, followed by ethane, propane, etc., due to the kinetic isotope effect (e.g. Sackett et al. 1968; Smith et al. 1971; Frank et al. 1974). In contrast, hydrocarbons synthesized from $\mathrm{CO}_{2}$ and $\mathrm{H}_{2}$ tend to show $\delta^{13} \mathrm{C}$ values that decrease in order from $\mathrm{CH}_{4}$ and $\mathrm{C}_{2} \mathrm{H}_{6}$. This distribution of carbon isotope ratios among gaseous hydrocarbons is referred to as the isotopic reversal (Jenden et al. 1993).

In this study, we measured variations in the carbon isotope ratios of hydrocarbons and discuss their geochemical implications for the origin and formation processes of hydrocarbons in the Sagara oil field in central Japan. 
FREE GAS SAMPLING

The drilling achieved a total depth of 200.6 meters (Hirano et al. this volume).

23 free gas samples were collected every morning during the drilling campaign from the top of the borehole using an acrylic bag. The recovered gas samples were immediately transferred to $5-\mathrm{cm}^{3}$ evacuated glass vials using a gas-tight syringe for measurement of the content and the isotope ratio of $\mathrm{CH}_{4}$ (methane) and $\mathrm{C}_{2} \mathrm{H}_{6}$ (ethane).

\section{IN SITU FLUID SAMPLING}

In situ fluid samples were collected on 13 February and 19 to 21 March 2002

within the borehole using the following in situ pressure sampler from desired intervals sectioned by packers: 58 m, 90 m, 135 m, and 162 m (oil sign, respectively), and $196 \mathrm{~m}$ (bottom of the borehole).

The sampler consists of a valve connected with a reservoir $400 \mathrm{~cm}^{3}$ in volume. The valve of the sampler can be controlled by He pressure from the ground so that the 
sampler can collect fluid samples without evaporation, degassing, and contamination during the ascent of the sampler. Gas and liquid phases were immediately isolated using the following procedures: first, the outlet of the sampler was connected to the Tygon tube, and the gas phase was transferred to a $5-\mathrm{cm}^{3}$ evacuated glass vial. After the gas phase was obtained, the liquid phase was taken into a $100-\mathrm{cm}^{3}$ glass vial (Ar-purged). The liquid samples were poisoned with $\mathrm{HgCl}_{2}$ as a preservative, and the glass vial was then capped with a gray butyl rubber septum. All samples were stored in the dark and at room temperature until analysis.

\section{ANALYTICAL METHOD}

The concentrations and stable carbon isotopic compositions of $\mathrm{CH}_{4}$ and $\mathrm{C}_{2} \mathrm{H}_{6}$ were measured using a continuous-flow gas chromatography isotope-ratio mass spectrometry (GC/IRMS) system (Tsunogai et al. 2002). The gas samples were injected into the analytical system using a gas-tight syringe through a silicon rubber septum. The liquid samples were introduced to a He-sparging bottle, and the stripped hydrocarbon 
gases were captured on a Porapak- $\mathrm{Q}$ trap at a liquid $\mathrm{N}_{2}$ temperature prior to introduction into the system. The extracted gases were then carried into the system by He carrier gas at a flow rate of $100 \mathrm{ml} / \mathrm{min}$.

The system consists of three functional units: (1) pre-concentration of $\mathrm{CH}_{4}$ and $\mathrm{C}_{2} \mathrm{H}_{6}$ gases; (2) subsequent chromatographic separation of the $\mathrm{CH}_{4}$ and $\mathrm{C}_{2} \mathrm{H}_{6}$ from the remaining non condensed gases in a GC oven; and (3) quantification of the ${ }^{13} \mathrm{C} /{ }^{12} \mathrm{C}$ ratio using the isotope-ratio mass spectrometer.

The pre-concentration trap is immersed in liquid $\mathrm{N}_{2}$ to collect the hydrocarbon gases. The pre-concentrated hydrocarbon gases are then cryo-focused in the front of the capillary column in liquid $\mathrm{O}_{2}$. The GC oven is mounted with a PoraPLOT-Q analytical capillary column (Chrompack) for final separation under the column oven temperatures ranging +30 to $+120^{\circ} \mathrm{C}$. The separated $\mathrm{CH}_{4}$ and $\mathrm{C}_{2} \mathrm{H}_{6}$ are converted to $\mathrm{CO}_{2}$ by combustion at a temperature of $960^{\circ} \mathrm{C}$ (Thermo Finnigan Combustion-II). The isotope-ratio mass spectrometer (Thermo Finnigan MAT 252) with a commercial open split interface (Thermo Finnigan Gas Bench) is employed to couple sample and reference $\mathrm{CO}_{2}$ flows via two open splits. 
The hydrocarbon content in the sample is determined by comparing the ${ }^{44} \mathrm{CO}_{2}$ output with that of a working standard gas, which is made from a NIST RM 8560 (IAEA NGS2) standard. The precision of the concentration determination was better than $6.5 \%$.

The isotope ratio of the hydrocarbons is analyzed with the isotope-ratio mass spectrometer in conjunction with ISODAT software. The carbon isotope ratios are reported relative to the PeeDee Belemnite (PDB) and are reported using the per mil notation, where:

$$
\delta^{13} \mathrm{C}=\left\{\left(\left({ }^{13} \mathrm{C} /{ }^{12} \mathrm{C}\right)_{\text {sample }} /\left({ }^{13} \mathrm{C} /{ }^{12} \mathrm{C}\right)_{\mathrm{PDB}}\right)-1\right\} \times 1,000 .
$$

The precision of the isotopic analysis for $\mathrm{CH}_{4}$ and $\mathrm{C}_{2} \mathrm{H}_{6}$ was estimated to be $0.3 \%$.

\section{RESULTS}

The concentrations and $\delta^{13} \mathrm{C}$ values of $\mathrm{CH}_{4}$ and $\mathrm{C}_{2} \mathrm{H}_{6}$ are shown in Tables 1,2 , 
and 3. The methane and ethane concentration in the free gas samples showed significant variation with depth (Table 1), particularly at 123.6 meters, where the methane and ethane concentration decreases dramatically down to $74 \mathrm{ppm}$ and $7.6 \mathrm{ppm}$, respectively, as shown in Table 1 . At this depth, the drilling pipe was broken by accident during the drilling expedition, which may have caused this decrease in hydrocarbon concentrations. The concentration of methane and ethane in the liquid samples also showed significant variations (Table 2). This variation suggests that the hydrocarbon gases are present under the cap rock layers, and the gases could not permeate the cap rocks themselves due to lithological and/or physicochemical factors.

The $\mathrm{CH}_{4} / \mathrm{C}_{2} \mathrm{H}_{6}$ ratios, however, are relatively constant with depth: (Tables 1, 2, and 3) $(9.8 \pm 2.7$ for the free gas, $9.4 \pm 4.5$ in the gas phase of the in-situ fluid sample, and $7.5 \pm 1.8$ in the liquid phase of the in-situ fluid sample where the error is given at a $1 \sigma$ level). This suggests that the hydrocarbons are chemically homogenous.

The $\delta^{13} \mathrm{C}_{\mathrm{CH} 4}$ values are relatively constant with depth, as shown in Tables 1,2 , and $3(-40.6 \pm 2.4 \%$ for the free gas, $-39.6 \pm 1.0 \%$ in the gas phase of the in-situ fluid sample, and $-37.8 \pm 1.6 \%$ in the liquid phase of the in-situ fluid sample). The $\delta^{13} \mathrm{C}_{\mathrm{C} 2 \mathrm{H} 6}$ 
values show no significant variation with depth, as shown in Tables 1, 2, and $3(-28.5 \pm$ $1.2 \%$ for the free gas, $-28.5 \pm 0.4 \%$ in the gas phase of the in-situ fluid sample, and $-27.8 \pm 0.6 \%$ in the liquid phase of the in-situ fluid sample). The isotopic distribution suggests that isotopically homogenous characteristics of the hydrocarbons exist in the Sagara oil field.

\section{DISCUSSION}

A combination of the $\mathrm{CH}_{4} / \mathrm{C}_{2} \mathrm{H}_{6}$ ratio with the carbon isotope ratio of methane can be used to classify the gases into various source types, microbial or thermogenic.

Carbon isotope ratios of $\mathrm{CH}_{4}$ compared to the $\mathrm{CH}_{4} / \mathrm{C}_{2} \mathrm{H}_{6}$ ratios of the core samples are shown in Fig. 2, together with data in the Nankai Trough (Berner \& Faber 1993). The data in the Nankai Trough can be explained by the mixing of methane of microbial origin and that of thermogenic origin, based on the cross-correlation of molecular composition and methane carbon isotope ratios (Berner \& Faber 1993). All the gases from the Sagara oil field indicate a clear thermogenic signature: $\delta^{13} \mathrm{C}\left(\mathrm{CH}_{4}\right)$ and a 
$\mathrm{CH}_{4} / \mathrm{C}_{2} \mathrm{H}_{6}$ ratio of -36 and $-46 \%$ and 4 to 16 , respectively (Tables 1,2 , and 3 ). This result suggests that microbial activity is negligible in the Sagara oil field.

Hydrocarbons formation by polymerization of methane precursors would show a pattern of isotopic reversal, with $\delta^{13} \mathrm{C}_{\mathrm{CH} 4}>\delta^{13} \mathrm{C}_{\mathrm{C} 2 \mathrm{H} 6}$ (Des Marais et al. 1981; Sherwood Lollar et al. 2002; Du et al. 2003). Differences between $\delta^{13} \mathrm{C}_{\mathrm{CH} 4}$ and $\delta^{13} \mathrm{C}_{\mathrm{C} 2 \mathrm{H} 6}$ in the samples are depicted in Tables 1, 2, and 3. The isotope compositions of methane are significantly lighter than those of ethane. This observed isotope pattern for hydrocarbon gases $\left(\delta^{13} \mathrm{C}_{\mathrm{CH} 4}<\delta^{13} \mathrm{C}_{\mathrm{C} 2 \mathrm{H} 6}\right)$ can be explained by a kinetic isotope fractionation where the ${ }^{12} \mathrm{C}-{ }^{12} \mathrm{C}$ bonds of source organic matter are preferentially cracked, leading to the formation of ${ }^{13} \mathrm{C}$-depleted gas hydrocarbons, with methane being the isotopically lightest compound (Andresen et al. 1995; Behar et al. 1997; Berner \& Faber 1997; Tang et al., 2000). The isotopic distribution obtained in this study suggests that the hydrocarbon gases in the Sagara oil field are not generated by polymerization, but by the decomposition of organic matter. The thermocatalytic decarboxylation $\left(\mathrm{R}-\mathrm{CO}_{2} \mathrm{H} \rightarrow \mathrm{R}-\mathrm{H}+\mathrm{CO}_{2}\right)$ of organic acid functional groups occurs in diverse environments with high temperatures $\left(>50^{\circ} \mathrm{C}\right)$, such as oil fields, geothermal fields, 
sediment-rich hydrothermal systems (e.g. Welhan \& Lupton 1987), and accretionary prisms at depths of 1,000 meters below the seafloor (Gamo et al. 1993; Berner \& Faber 1993; Fig. 2).

Our molecular and isotopic analysis of hydrocarbons in the free gas and in situ fluid from the Sagara oil field suggest that the formation process of the hydrocarbons appears to be organic matter decomposition. Furthermore, the isotopic compositions of $\mathrm{CH}_{4}$ and $\mathrm{C}_{2} \mathrm{H}_{6}$ are consistently depleted with regard to ${ }^{13} \mathrm{C}$ compared to the composition of the Sagara oil itself (-24.5\%oPDB; Kato 1992). Thus, the thermal decomposition of organic matter, including Sagara oil, to produce methane and ethane appears to be the most important source for these hydrocarbons.

\section{CONCLUSIONS}

We measured the concentration ratios of $\mathrm{CH}_{4} / \mathrm{C}_{2} \mathrm{H}_{6}$ and the carbon isotope ratios for gas samples from the Sagara oil field. The results show that the $\mathrm{CH}_{4} / \mathrm{C}_{2} \mathrm{H}_{6}$ ratio is 4 to 16 and that the $\delta^{13} \mathrm{C}\left(\mathrm{CH}_{4}\right)$ is between -36 and $-46 \%$, suggesting that the 
hydrocarbons are of thermogenic origin. Based on the isotope signature of hydrocarbon gases of $\delta^{13} \mathrm{C}_{\mathrm{CH} 4}<\delta^{13} \mathrm{C}_{\mathrm{C} 2 \mathrm{H} 6}$, we conclude that the formation process for hydrocarbon gases involves a thermocatalytic breakdown of organic carbon compounds and is not associated with hydrocarbons synthesis.

\section{ACKNOWLEDGMENTS}

We would like to thank A. Taira, T. Imanaka, H. Wada, N. Suzuki, H. Kitazato,

S. Hirano, and K. Oguri for organizing the remarkably successful SDP expedition, and the engineers and operation team of Kawasaki Geological Engineering Co. Ltd. for their valuable operation. We also would like to thank K. Sawada, K. Kato, H. Imanaka, H. Saito, and H. Oida for their cooperation with the sample collection, and H. Obata, M. Tsutsumi (University of Tokyo), F. Nakagawa, and A. Ijiri (Hokkaido University) for stimulating discussion throughout this study.

\section{REFERENCES}


ANDRESEN B., THRONDSEN T., RAHEIM A. \& BOLSTAD 1995. A comparison of pyrolysis products with models for natural gas generation. Chemical Geology 126, 261-80.

Behar F., VANDENBRoucKe M., TANG Y., MARQUiS F. \& ESPITALIE J. 1997. Thermal cracking of kerogen in open and closed systems: determination of kinetic parameters and stoichiometric coefficients for oil and generation. Organic Geochemistry 26, 321-39.

BERNER U. \& FABER E. 1993. Light hydrocarbons in sediments of the Nankai accretionary prism (Leg 131, site 808). In Winkler W. R. and Stewart N. J. (eds.) Proceedings of the Ocean Drilling Program, Scientific Results, Vol. 131, pp. 185-95, Ocean Drilling Program, Texas.

BERNER U. \& FABER E. 1997. Empirical carbon isotope/maturity relationships for gases from algal kerogens and terrigeneous organic matter, based on dry, open-system pyrolysis. Organic Geochemistry 24, 947-55.

Des Marais D. J., DonChin J. H., Nehring N. L. \& Truesdell A. H. 1981. 
Molecular carbon isotopic evidence for the origin of geothermal hydrocarbons.

Nature 292, 826-28.

DU J., JIN Z., XIE H., BAI L. \& LIU W. 2003. Stable carbon isotope compositions of gaseous hydrocarbons produced from high pressure and high temperature pyrolysis of lignite. Organic Geochemistry 34, 97-104.

FRANK D. J., GORMLY J. R. \& SACKETT W. M. 1974. Revaluation of carbon-isotope compositions of natural methanes. The American Association of Petroleum Geologists Bulletin, 58 2319-25.

GAMO T., KASTNER M., BERNER U. \& GIESKES J. 1993. Carbon isotope ratio of total inorganic carbon in pore waters associated with diagenesis of organic material at the ODP Site 808, Nankai Trough. In Winkler W. R. and Stewart N. J. (eds.) Proceedings of the Ocean Drilling Program, Scientific Results, Vol. 131, pp. 159-63, Ocean Drilling Program, Texas.

HIRANO H., ARAKI Y., WADA H. \& SAGARA DRILLING PROGRAM SCIENTIFIC PARTY 2003. Lithology and physical properties of core samples obtained from the Sagara oil field, central Japan: Preliminary results of the Sagara Drilling 
Program (SDP). Frontier Research on Earth Evolution 1, 253-5.

IBARAKI M. 1986. Planktonic foraminferal datum levels recognized in the Neogene sequence of the Kakegawa area, and their relationship with the lithostratigraphy (in Japanese with English abstract). Journal of the Geological Society of Japan 92, 119-34.

Jenden P. D., Hilton D. R., KAPlan I. R. \& CRAig H. 1993. In Howell D. (ed.) The future of Energy Gases (U.S. Geological Survey Professional Paper 1570), pp. 31-56.

KaTO S. 1992. Petroleum Geology of the Omaezaki District, Shizuoka Prefecture —hydrocarbon Potential in Fore-arc Basins — (in Japanese with English abstract). Journal of the Japanese Association for Petroleum Technology 57, 45-52.

MORIKAWA M. \& IMANAKA T. 1993. Isolation of a new mixotrophic bacterium which can fix $\mathrm{CO}_{2}$ and assimilate aliphatic and aromatic hydrocarbons anaerobically. Journal of Fermentation and Bioengineering 76, 280-3.

MORIKAWA M., IWASA T., YANAGIDA S. \& IMANAKA T. 1998. Production of 
alkane/alkene from $\mathrm{CO}_{2}$ by a petroleum-degrading bacterium. Journal of

Fermentation and Bioengineering 85, 243-5.

RiCE D. D. \& CLAYPOOL G. E. 1981. Generation, accumulation and resource potential of biogenic gas. The American Association of Petroleum Geologists Bulletin 65, $5-25$.

SACKETT W. M., NAKAPARKSIN S. \& DALRYMPLE D. 1968. Carbon isotope effects in methane production by thermal cracking. In Shenck P.A. and Havenaar I. (eds.) Advances in Organic Geochemistry, pp. 37-53, Pergamon, Oxford.

SCHOELl M. 1983. Genetic characterization of natural gases. The American Association of Petroleum Geologists Bulletin 67, 2225-8.

SHerWoOd Lollar B., Westgate T. D., WARD J. A., Slater G. F. \& LACRAMPE-COULOUME G. 2002. Abiogenic formation of alkanes in the Earth's crust as a minor source for global hydrocarbon reservoir. Nature 416, 522-24.

Shiba M., SAGo K., KaWABE M., TAKeshima H., MuraKami Y., YoKOYAMA K. \& SuRUGA BAy COLLABORATIVE RESEARCH GROUP 1996. Stratigraphy of the Sagara Group and the Kakegawa Group in Haibara district, Shizuoka prefecture, 
central Japan (in Japanese with English abstract). Earth Science (Chikyu Kagaku) 50, 441-55.

SHIBA M., SOUZUKA J., YAMAdA T., HigASHIMOTO M., KIKUCHI M. \& KosAKA T. 1997. Planktonic foraminiferal biostratigraphy of the Sagara and Kakegawa Groups in the Haibara district, Shizuoka prefecture, central Japan (in Japanese with English abstract), Earth Science (Chikyu Kagaku) 51, 263-78.

SMith J. E., ERDMAN J. G. \& MORRIS D. A. 1971. Migration, accumulation and retention of petroleum in the earth. 8th World Petroleum Congress proceedings 2, 13-26.

TANAKA A., YANO Y., SASADA M., OKUBO Y., UMEDA K., NAKATSUKA N. \& AKITA F. 1999. Compilation of thermal gradient data in Japan on the basis of the temperatures in boreholes. Bulletin of the Geological Survey of Japan 50, 457-87.

TANG Y., PERRY K., JENDEN P. D. \& SCHOELL M. 2000. Mathematical modeling of stable isotope ratios in natural gases. Geochimica Cosmochimica Acta 64, 2673-87. 
TSUCHI R. 1961. On the late Neogene sediments and mulluscs in the Tokai region, with notes on the geologic history of the Pacific coast of Southwest Japan (in Japanese with English abstract). Japanese Journal of Geology and Geography 32, 437-56.

TSUNOGAI U., YoshidA N. \& GAMO T. 2002. Carbon isotopic evidence of methane oxidation through sulfate reduction in sediment beneath cold seep vents on the seafloor at Nankai Trough. Marine Geology 187, 145-60.

UEMURA T. \& YAMADA T. 1988. (eds.) Regional Geology of Japan, Part 4 Chubu I, Kyoritsu Shuppan, Tokyo, 332pp.

UJIIE H. 1962. Geology of Sagara-Kakegawa sedimentary basin in central Japan (in Japanese with English abstract). Science reports of the Tokyo Kyoiku Daigaku 8, 123-88.

WELHAN J. A. \& LUPTON J. E. 1987. Light hydrocarbon gases in Guaymas basin hydrothermal fluids: thermogenic versus abiogenic origin. The American Association of Petroleum Geologists Bulletin 71, 215-23. 
Figure legends

Fig. 1 Location map of the Sagara oil field

Fig. 2 Plot of $\delta^{13} \mathrm{C}_{\mathrm{CH} 4}$ vs. $\mathrm{CH}_{4} / \mathrm{C}_{2} \mathrm{H}_{6}$ ratio of free gas samples (solid diamond), gas phase in fluid samples (open diamond), and liquid phase in fluid samples (open circle), together with those of gases from Nankai Trough (cross; Berner and Faber, 1993). 


\section{$130^{\circ} \mathrm{E}$}

$140^{\circ} \mathrm{E}$

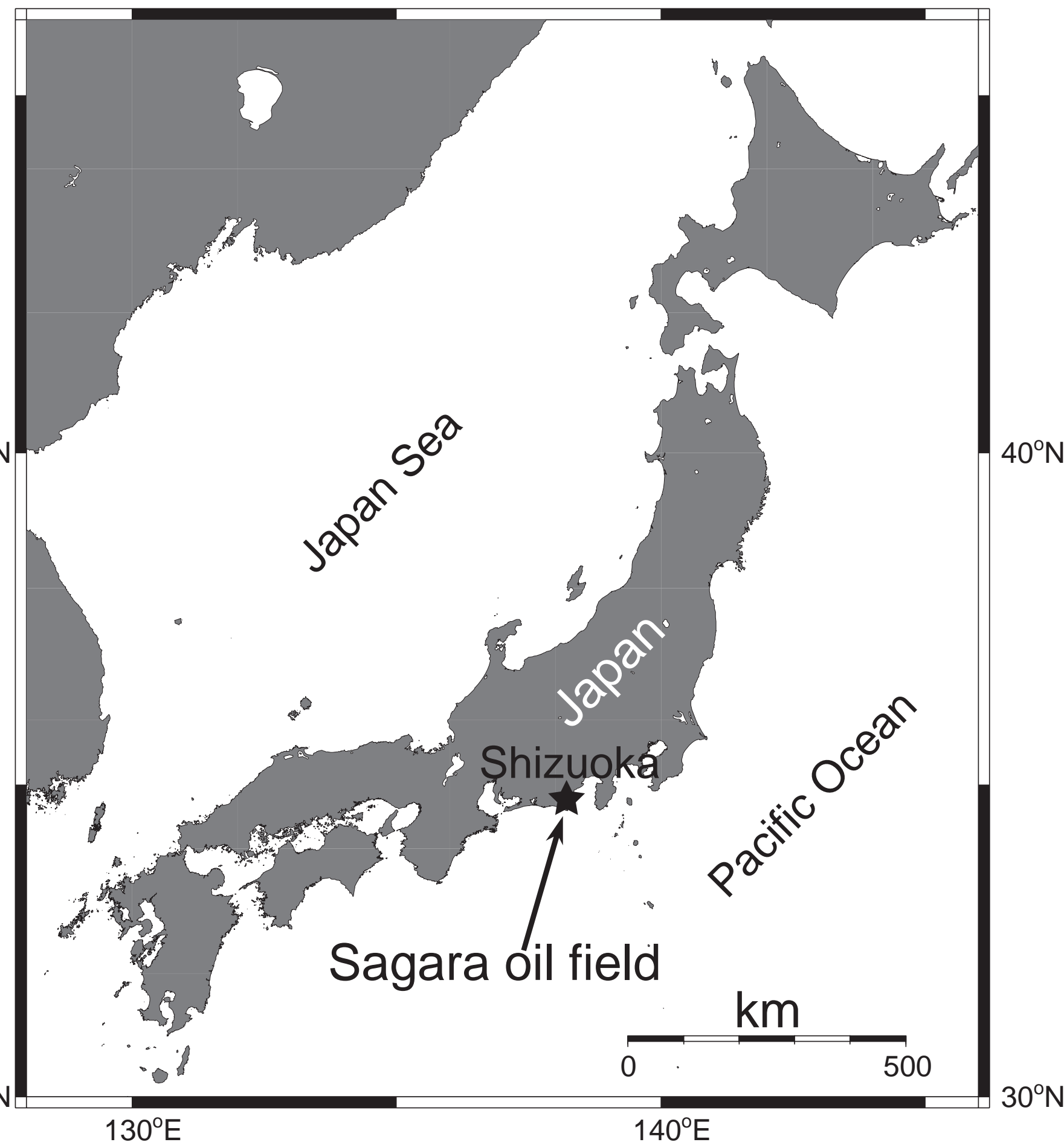

Fig. 1 


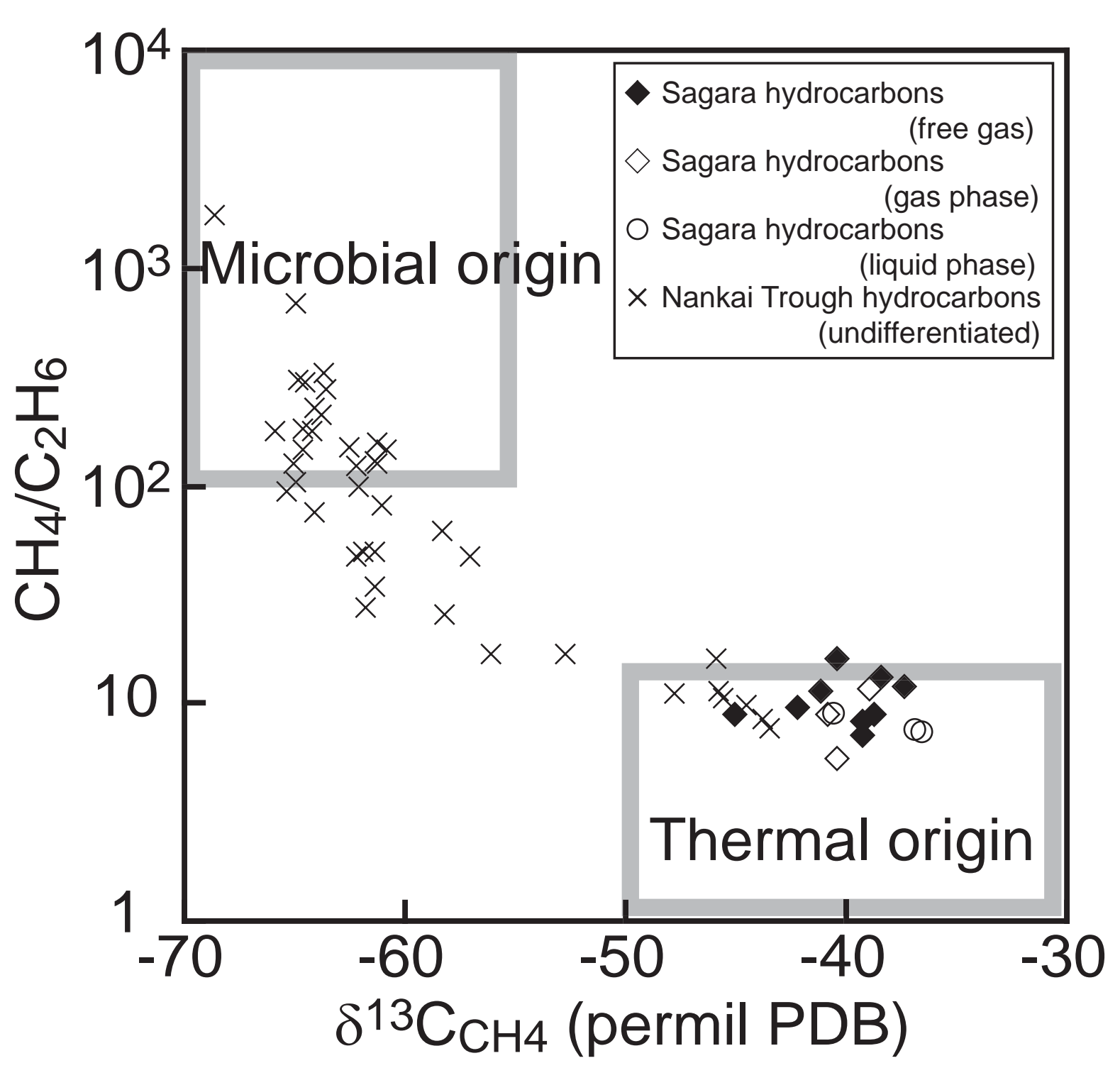

Fig. 2 
Table 1 Content and isotopic composition of methane and ethane, respectively, and content ratio of methane to ethane in free gas samples

\begin{tabular}{|c|c|c|c|c|c|}
\hline $\begin{array}{c}\text { Depth } \\
\mathrm{m}\end{array}$ & $\begin{array}{c}\mathrm{CH}_{4} \\
\% \\
\end{array}$ & $\begin{array}{c}\delta^{13} \mathrm{C}\left(\mathrm{CH}_{4}\right) \\
\text { permil PDB }\end{array}$ & $\begin{array}{c}\mathrm{C}_{2} \mathrm{H}_{6} \\
\% \\
\end{array}$ & $\begin{array}{l}\delta^{13} \mathrm{C}\left(\mathrm{C}_{2} \mathrm{H}_{6}\right) \\
\text { permil PDB }\end{array}$ & $\mathrm{CH}_{4} / \mathrm{C}_{2} \mathrm{H}_{6}$ \\
\hline 60.3 & 12 & -44.4 & 0.80 & -30.1 & 14 \\
\hline 67 & 0.86 & -42.1 & 0.075 & -29.6 & 11 \\
\hline 70 & 3.2 & -39.1 & 0.33 & -28.1 & 9.6 \\
\hline 74.8 & 35 & -41.2 & 2.7 & -29.0 & 13 \\
\hline 87.3 & 13 & -45.0 & 1.8 & -29.7 & 7.2 \\
\hline 92.2 & 50 & -42.2 & 3.1 & -29.2 & 16 \\
\hline 99.8 & 14 & -38.1 & 1.2 & -28.0 & 12 \\
\hline 107.1 & 13 & -38.5 & 1.5 & -27.9 & 9.0 \\
\hline 101.3 & 21 & -39.2 & 2.3 & -28.4 & 9.0 \\
\hline 110.1 & 18 & -39.0 & 2.2 & -27.8 & 8.3 \\
\hline 119.85 & 1.2 & -38.1 & 0.14 & -27.4 & 8.9 \\
\hline 123.6 & 0.0074 & -41.5 & 0.00076 & -26.2 & 9.8 \\
\hline 126.65 & 0.029 & -39.3 & 0.0038 & -27.9 & 7.8 \\
\hline 136.65 & 19 & -38.3 & 4.0 & -28.8 & 4.9 \\
\hline 141.1 & 2.3 & -40.4 & 0.42 & -28.4 & 5.5 \\
\hline 149.35 & 4.7 & -43.3 & 0.46 & -26.2 & 10 \\
\hline 156.45 & 21 & -37.4 & 2.6 & -27.3 & 8.1 \\
\hline 164 & 1.7 & -43.7 & 0.21 & -30.3 & 8.0 \\
\hline 171.75 & 23 & -38.7 & 3.0 & -28.2 & 7.8 \\
\hline 185 & 4.7 & -40.6 & 0.40 & -28.5 & 12 \\
\hline 191.6 & 0.61 & -45.1 & 0.067 & -31.0 & 9.1 \\
\hline 197.7 & 6.8 & -39.5 & 0.61 & -28.5 & 11 \\
\hline 200.6 & 6.2 & -39.2 & 0.52 & -28.7 & 12 \\
\hline Average & & -40.6 & & -28.5 & 9.8 \\
\hline$\sigma$ & & 2.4 & & 1.2 & 2.7 \\
\hline
\end{tabular}


Table 2 Content and isotopic composition of methane and ethane, respectively, and content ratio of methane to ethane in gas phase of fluid samples

\begin{tabular}{|c|c|c|c|c|c|}
\hline $\begin{array}{c}\text { Depth } \\
\mathrm{m}\end{array}$ & $\begin{array}{c}\mathrm{CH}_{4} \\
\% \\
\end{array}$ & $\begin{array}{l}\delta^{13} \mathrm{C}\left(\mathrm{CH}_{4}\right) \\
\text { permil PDB }\end{array}$ & $\begin{array}{c}\mathrm{C}_{2} \mathrm{H}_{6} \\
\% \\
\end{array}$ & $\begin{array}{l}\delta^{13} \mathrm{C}\left(\mathrm{C}_{2} \mathrm{H}_{6}\right) \\
\text { permil PDB }\end{array}$ & $\mathrm{CH}_{4} / \mathrm{C}_{2} \mathrm{H}_{6}$ \\
\hline 58.25 & 32 & -40.9 & 3.5 & -28.9 & 9.0 \\
\hline 90 & 5.6 & -39.2 & 0.49 & -28.2 & 12 \\
\hline 135 & 16 & -38.9 & 2.9 & -28.0 & 5.5 \\
\hline 162 & 1.0 & -38.4 & 0.19 & -28.2 & 5.1 \\
\hline 195.5 & 23 & -40.5 & 1.5 & -29.0 & 16 \\
\hline Average & & -39.6 & & -28.5 & 9.4 \\
\hline$\sigma$ & & 1.0 & & 0.4 & 4.5 \\
\hline
\end{tabular}


Table 3 Concentration and isotopic composition of methane and ethane, respectively, and concentration ratio of methane to ethane in liquid phase of fluid samples

\begin{tabular}{|c|c|c|c|c|c|}
\hline $\begin{array}{c}\text { Depth } \\
\mathrm{m}\end{array}$ & $\begin{array}{c}\mathrm{CH}_{4} \\
\mathrm{mmol} / \mathrm{kg}\end{array}$ & $\begin{array}{c}\delta^{13} \mathrm{C}\left(\mathrm{CH}_{4}\right) \\
\text { permil PDB }\end{array}$ & $\begin{array}{c}\mathrm{C}_{2} \mathrm{H}_{6} \\
\mathrm{mmol} / \mathrm{kg}\end{array}$ & $\begin{array}{l}\delta^{13} \mathrm{C}\left(\mathrm{C}_{2} \mathrm{H}_{6}\right) \\
\text { permil PDB }\end{array}$ & $\mathrm{CH}_{4} / \mathrm{C}_{2} \mathrm{H}_{6}$ \\
\hline 58.25 & 3.4 & -40.5 & 0.38 & -28.2 & 9.0 \\
\hline 90 & 2.5 & -37.1 & 0.33 & -27.3 & 7.5 \\
\hline 135 & 4.8 & -36.9 & 0.65 & -27.7 & 7.4 \\
\hline 162 & 0.27 & -38.0 & 0.058 & -28.7 & 4.7 \\
\hline 195.5 & 3.7 & -36.5 & 0.040 & -27.3 & 9.1 \\
\hline Average & & -37.8 & & -27.8 & 7.5 \\
\hline$\sigma$ & & 1.6 & & 0.6 & 1.8 \\
\hline
\end{tabular}

